\title{
Factors Affecting Number of Women Ward Councillors in South Africa
}

\author{
Brian Kwazi Majola*
}

\author{
Department of Business Management (HR Programme), University of Limpopo, Turfloop Campus, \\ Polokwane, South Africa
}

\begin{abstract}
The number of women elected into political positions has been a challenge for both developed and developing states. Countries that have introduced national prescripts and ratified the United Nations conventions continue to struggle with women's representation and participation in politics, especially at the local government level. South Africa is not an exception to this. Despite legislation that appears to enable gender equality in local structures, the number of women ward councillors has been fluctuating since the reformation of local government after 1994. The objective of this paper is to investigate factors affecting the number of women elected as ward councillors in South Africa. The paper adopts an exploratory research design and is qualitative in nature. It focuses on six local municipalities of the KwaZuluNatal and Eastern Cape Provinces. Males and female ward and proportional representative councillors were interviewed using face-to-face and telephone techniques. The findings of the study were analysed using content analysis and themes were generated from the interview data. The study revealed that there are more women proportional representative councillors than ward councillors, which confirms the challenge with regard to women's representation in local politics. The number of women councillors is low and some major factors identified in the study were lack of confidence, education and community involvement; cultural influence; and competitiveness amongst women.
\end{abstract}

Keywords: Ward councillors, representation, participation, gender, elections.

\section{INTRODUCTION}

Worldwide, there has been some improvement in terms of women's political participation in the past few decades. Within politics, women can play a variety of roles as voters, political party members, candidates and office holders and members of civil society (Markhams 2013). However, this progress has been slow in relation to the election of women ward councillors at the local level even after the 1995 United Nations (UN) Beijing Conference. The aim of the conference was to achieve greater equality and opportunity for women in all aspects of life (UNDP, 2015). Most countries ensure that women numbers are met at the national level of government, ignoring the local level where the government is closer to the people. It is at this level where women are struggling to be elected into positions although women constitute the majority of the population and are the most affected when the government does not deliver. Countries that have introduced national prescripts and ratified the UN conventions are struggling with women's election into political positions at the local government level (International IDEA, 2016). South Africa is not an exception to this. Despite legislation that appears to enable gender equality and equal representation in local structures, the number of women ward councillors has been fluctuating since the reformation of local

*Address correspondence to this author at the Department of Business Management (HR Programme), University of Limpopo, Turfloop Campus, Polokwane, South Africa; Tel: +2715 2683805; E-mail: majolabk@ymail.com government in 1995/6. The objective of this paper is to investigate factors affecting the number of women elected as ward councillors in South Africa.

This paper unpacks and explores the UN convention, South African legislation and other structures that promote representation and participation of women at the local government level. The paper then explain the methods used, presents and discuss the findings as well as the conclusion of the study. The paper will enable political parties; government and its institutions; communities and civil society groups; policymakers and municipalities understand the reality on the ground and attempt to address the identified factors affecting women ward councillors in South Africa.

\section{LITERATURE REVIEW}

\subsection{International and National Legal Framework on Women and Local Government}

\subsubsection{The United Nations on Women's Rights}

A number of UN conventions and recommendations were introduced and ratified by member states. This include the UN Convention on Ending All Discrimination Against Women (CEDAW) (1979) and the Beijing Platform for Action (1995). CEDAW's Article 7 to 9 ensures that women are provided with rights to representation and nationality. Women need to participate in all areas of human activity namely, equal access to education, employment opportunities and 
adequate health services including political participation. The UN Women office is the latest office established to fight for the rights of women in different countries. The UN Women aims to address inequalities, inadequacies, and unequal access to education and training as well as inequality between men and women in the sharing of power and decisionmaking at all levels. The Southern African Development Community (SADC) Protocol on Gender and Development (2008) encouraged South Africa to recognize the rights of women as unchallengeable rights.

\subsubsection{The Constitution and the White Paper on Local Government in South Africa}

The Constitution (Republic of South Africa 1996), chapter 2 has a clause on equality, which reveals a guarantee to promote gender equality and ensure that women enjoy equal rights. Local government is enshrined in Chapter 7 of the Constitution. The Constitution places an obligation on the local government to encourage the involvement of communities and community organizations in matters of local government (CLGF 2017). Building on the Constitution, the 1998 White Paper on Local Government paved the way for a modern local government system with clear developmental objectives (DPME 2017). The White Paper on Local Government (1998) commits the local government to meet citizen's needs through people-driven participatory methods (SALGA Women's Commission 2017). Municipalities are primarily responsible for providing quality, cost-effective municipal services (DPME 2017) where women are beneficiaries and supposed to enjoy full representation. The White Paper on Local Government (1998), which is considered as the "mini-constitution" allows municipalities "to assess the impact of their strategies on women and ensure that the needs and interests of women are incorporated into municipal planning processes". In addition, the emphasis is on accountability that strengthens the role of councillors for the benefit of all community groups including women. Political parties were also encouraged to adopt a quota system in order to address gender inequalities at all levels of governance.

\subsubsection{The Municipal Structures Act No. 117 of 1998}

The Municipal Structures Act (1998) expressly requires political parties to take practical steps to promote the representation of women (Selokelo 2014). Parties are expected to pay attention to day-to-day realities such as poor service delivery, unemployment and housing (Mandyoli 2016). Furthermore, the Local Government Municipal Structures Act requires the equal distribution of male and female candidates on political party lists. Notwithstanding the progressive nature of this legislation, evidence suggests that women remain under-represented in local municipal councils (Selokelo 2014). According to Selokelo (2014), political parties are not implementing the provisions of the Act, as an inadequate representation of women, councillors indicates, due to the ineffective and nonpre-emptory language found in the Act itself. There are no penalties for not putting women on top of the party list during local elections.

\subsubsection{The Municipal Systems Act No. 32 of 2000}

The Municipal Systems Act (2000) obliges a municipality to create the systems, mechanisms and enabling conditions for meaningful participation of the community in the affairs of the municipality. The Act requires councillors and officials to play a key role in fostering community participation. However, many councillors have become estranged from communities and their critical concerns. Women are good community mobilisers for a broad range of initiatives, including community-based activities and projects aimed to support political parties (Nhundu 2008). However, the link between councillors and citizens via the ward committee system needs to be improved (DPME 2017). Women politicians are motivated to address women's issues and bring a gender perspective into policies because of their need to gain support among voters, especially women voters.

\subsection{The Supply-Side and Demand-Side Framework}

In order to understand the factors affecting the number of women councillors, it is important to focus on the demand-side and supply-side factors. According to Norris and Lovenduski (1995), the supply-side deals with the source of candidates and had two sub-factors namely, individual resources and motivation. Women have fewer resources such as time, money, skills, compared to men. Motivation refers to the drive, training or education, personal networking, mentoring, ambition and interest in politics (Krook 2010). A supplyside perspective suggests that political parties should focus on promoting conditions and opportunities that lead women to aspire for political office (International IDEA 2016).

Women's availability to be in politics is influenced by the demand-side factors including the country's electoral systems or political parties; social structures 
and civil society. Political parties and voters focus on women's qualifications, abilities and experiences before their names are on the list. Therefore, political parties should change their candidate selection procedures, evaluate their criteria for suitable candidates and reassess how they present their female candidates to the electorate (International IDEA 2016). Boeteng and Kosi (2015) argued that the supply of women available for political office is determined partly by gender socialization, which influences women's interest, knowledge, and ambition regarding politics.

\subsection{Gender Socialisation}

Gender refers to characteristics, opportunities and relationships associated with being female or male, and sociocultural relationships between women and men, and girls and boys (Meena, Rusimbi, Israel 2017). Social inclusion is a process of improving the terms of participation in society for people who are disadvantaged on the basis of age, sex, disability, race, ethnicity, origin, religion or economic or other status, through enhanced opportunities, access to resources, voice, and respect for rights under target 10.2 of the 2030 Agenda (UN Chapter1 2016: 20). The State can play a role and contribute to the inclusion discourse by providing opportunities for education, health, employment, political participation, civic and cultural life. However, Cardo (2014) urged that not all inclusion is equitable as members may still face discrimination.

Social exclusion is a result of power relations between individuals and social groups and can occur in three realms namely, the public (government institutions), private (family, ethnic group, marriage) and intimate. The intimate is the way one feels excluded within oneself, expressed usually in terms of low self-confidence, self-esteem, control over our bodies (Batliwala and Veneklasen, 2012). According to Khan and Ara (2006), patriarchal norms and state laws keep women councillors in a lower status than men which result in their lower self-confidence. A study conducted by Bleidorn, Denissen, Gebauer, Arslan, Rentfrow and Potter (2016) show that men tend to have higher self-esteem than women do and that both genders show age-graded increases in self-esteem from late adolescence to middle adulthood. Nahar and Humaidan (2013) argued that women themselves do not elect women because the electoral decisions are still not independent, instead of being subject to the masculine authority and to the customs and traditions that promote the status of men and reduce or marginalize the public presence of females.

\subsection{Factors Affecting Women's Political Participation}

Women's political participation and the number of ward councillors is affected by a number of factors. However, one must mention that these factors are not the same everywhere in the world.

\subsubsection{Personal and Individual Factors}

Personal factors refer to psycho-social attributes which entail women's personality, attitudes and behavioural skills (Kasomo 2012). Whereas, individual factors are determined by personal traits that include personal goals they set themselves and their determination to make a difference; the knowledge competencies and skills they have for undertaking a political career; the resources or capacity they have to mobilise resources for electoral campaigns (Meena et al. 2017). These factors can be associated and understood better by looking at the Supply-Side and Demand-Side factors as discussed above.

\subsubsection{Family and Community Factors}

Furthermore, family and community factors are based on the groundwork for women's political leadership which lies in socialisation processes that begin in the family and community (Meena et al. 2017).

\section{Family Influence and Support for Women's Political} Participation

Women are seen as inferior, weak and cannot be trusted in making informed decisions which makes it a challenge for them to enter politics. With partner's support and having grown up children a woman can enjoy her political career, otherwise, she may end up being divorced. This means that a husband can accompany his wife to an evening meeting with community members. In this way, the woman ward councillor can feel protected and competent to perform her duties. Nasreen et al. (2016) revealed that almost all of the elected women ward councillors in Pakistan came from the joint family system which helped them in carrying out their political activities. One women councillor stated that the sister-in-law took care of the children whenever she is away on political duties. In Uganda, a young woman had to promise the electorate that she could find a partner and get married, and that this domestic and personal quest was next on her agenda, as soon as she had won the seat (Ahikire 2004). Only women with supportive families run for office, whereas men are more likely to run in spite of discouragement from their families (Silbermann 2019). 
The study conducted in Tanzania shows that parents played a central role in the empowerment, either by investing in their daughter's education or by inspiring them and serving as a role model to them. Furthermore, most women indicated that their spouses supported their leadership journey by providing emotional support and the financial resources needed, and by helping them to maintain a family-work balance (Meena et al. 2017).

Community Structures and Civil Society's Role in Women's Political Participation

Women in civil society organizations have been at the forefront of the political struggles in some parts of the world. Due to political parties being banned in the 1960 s, civil society organizations were the voice of the voiceless in South Africa. Learning and exposure received through working with communities facilitated the election of women as ward councillors after 1994. However, Parke et al. (2017) warned that women's organizations and female politicians are not necessarily working towards a common goal but compete with each other. Many women leaders have a negative perception of formal politics and consider work in civil society as a more effective means of contributing to positive change (Spark and Corbett 2016). In the post1994 era, South Africa's civil society has been less active although there are organizations such as Equal Education; Social Justice Coalition; and Abahlali BaseMjondolo. Civil society has challenges caused by lack of funding, working in silos, afraid to be labelled as anti-democratic or anti-ANC or be regarded as fronts for apartheid era-groups.

\subsubsection{Cultural Factors}

Bauer and Britton (2006) argued that the existence of a patriarchal culture is one of the factors contributing to the low number of women's political representation and participation. The acquisition of culture is a result of the socialization process (Idanga 2015). Women's gender identity is still predominantly conceived as being domestic in nature and continues to act as a barrier to women's entry into formal politics (Mlambo and Kapingura 2019). Therefore, cultural ideas about women can affect women's level of representation throughout the political process, from an individual women's decision to enter politics to party selection of candidates, to decisions made by voters on election day (Kunovich, Paxton and Hughes 2007; Kassa 2015). In communities where women's roles as politicians and decision-makers are not well accepted, women face strong cultural barriers entering local government (Nhundu 2017). Even in countries like the USA, where women have gained in employment or education, they still face cultural barriers to participate in politics (Kunovich et al. 2007; Kassa 2015). Like other countries, South Africa is a patriarchal society that keeps women in a subordinate position, using religion and culture as an excuse (Kassa 2015). Women in the urban area participate more in politics than those in rural areas under the traditional authority and councils. Ethnic division strengthens patriarchal structures which limit women's involvement in society.

\subsubsection{Economic Factors}

Socio-economic factors are where women cannot secure the necessary funding for campaigns as they have limited control over resources and have no economic networks.

\section{Inadequate Funding}

According to Rosenbluth, Kalla and Teele (2015), women politicians receive fewer private donations on average than their male counterparts and rely relatively more on party sponsorship and support. At a local government level, with inadequate funding for a successful campaign, women's political career is doomed. Women come off second best when money dominates politics. Mlambo and Kapingura (2019) argued that the government should provide more funds to independent women politicians and also to political parties that have a considerable and acceptable number of women political candidates.

\section{The Role of Education and Training on Women Political} Participation

Mlambo and Kapingura (2019) also warned that women need to be educated and be informed that political participation is not limited to election campaigns and mobilization. Nonetheless, Goetz (2003) argue that education realization does not automatically result in increased numbers of women in formal politics as gender gap continued besides reaching gender equality in education. The study by Nsana and Kabubi (2017) found that lack of access to well-developed education and training systems for women's political leadership and for orienting young women towards political life is a cause for their lack of participation. According to Mungai (2014), while all women councillors interviewed reported receiving training on campaign skills before elections, very few had received training after they were elected. Women councillors felt that they must be trained on their role and responsibilities or public speaking, and on budgets 
as they lack basic financial skills. In South Africa, everyone is allowed to study wherever they want, however, many are restricted by financial constraints (Segalo 2015).

\subsubsection{Political Factors}

Politics almost everywhere is a male-oriented, maledominated enterprise and female political participation is not as good as expected (Kaasa 2015). Nhundu et al. (2017) argued that male-dominated political parties are not willing to involve women in their local branches and in local politics. Tunde (2014) pointed out that in order to change male-dominated political cultures, all political parties should adopt appropriate measures and policies, such as party quotas, transparent criteria and party-list placement designed to promote the election of women, along with funding for women candidates and women party members.

\section{Gender Quota System}

The countries that have the highest number of women in local governments are the ones that implemented some kind of affirmative action measures such as gender quotas (Nhundu et al. 2017). The adoption of the quota policy by political parties can improve the representation of women local government (Meintjes and Simons 2002; Tolmay and Morna 2010). However, gender quota system has political challenges as women may be perceived as less capable (O'Neil and Domingo 2016); quotas can act as an upper ceiling to women's participation (Baker 2015); and legislated quotas involve women competing against other women rather than supporting each other (International Women's Development Agency 2018). Furthermore, in the Philippines, $60 \%$ of the women disagree with the idea of reserving $30 \%$ of seats for women automatically and only $40 \%$ were in favour of the gender quota system (Zapata 2018).

\section{The Role of Political Parties}

Selokelo (2014) states that the political party decides the order in which the names appear which may easily favour male candidates if they are placed ahead of females. Moreover, the selection of the candidates, regardless of gender, is in accordance with the preference of a political party (Selokelo 2014). Nonetheless, political party leaders argued that there is a shortage of willing and trained women candidates with the requisite confidence and experience to stand for election (Markhams 2013; Nsana and Kabubi 2017). On the other hand, the UNDP (2015) remarked that political parties have not addressed the challenges facing women and have not generally provided special assistance to attract them to the political arena. In a study by Tunde (2014) all women aspirants interviewed unveiled that they had not received any support from their political parties and government which made their entry into politics a challenge.

\section{Women, Killings and Violent Nature of Politics}

In most African countries, politics is tarnished by violence, persecution, intimidation and torture (Mlambo and Kapingura 2019). Women often face violence and interference against their political voice starting from home, where they may be intimidated, harassed or even abused by their husbands in order to keep them from voting or to force them to vote for a specific candidate (Nsana and Kabubi 2017). Women are intimidated, harassed and even killed by communities and male competitors from within and outside their political parties during campaigns. Therefore, political violence and the stigma that politics is a dirty game is a challenge for women to enter (Mlambo and Kapingura 2019). Violence against women in politics poses a serious challenge to democracy, human rights and gender equality (Nsana and Kabubi 2017). There had been more than 12450 political assassinations in the Province of KwaZulu-Natal since the end of apartheid in 1994 (Bruce 2013). About 90 politicians including women have been killed allegedly by members of the same political party since 2016 because they were witnesses in certain cases; spoken against corruption in the party or municipality, or just competing for ward seats.

\subsection{Women at Local Level in South Africa}

The population of South Africa is estimated at 58.083 million (UN Estimates 2019). There are more women than men in South Africa and the female population is on average poorer than the male population (StatsSA 2019). It is argued that women participate in greater numbers in local-level politics with the purpose to fight against under-representation in decision-making positions (Phillips 1996; Hassim 2005) than at national level because they can juggle political work with their domestic responsibilities (Robinson 1995; Fick 2000). However, women are underrepresented in ward seats, making the composition of any council uneven (Selokelo 2014). Including women in local government is an essential step towards creating gender-equal governments and gendersensitive policies (Nhundu et al. 2017). 


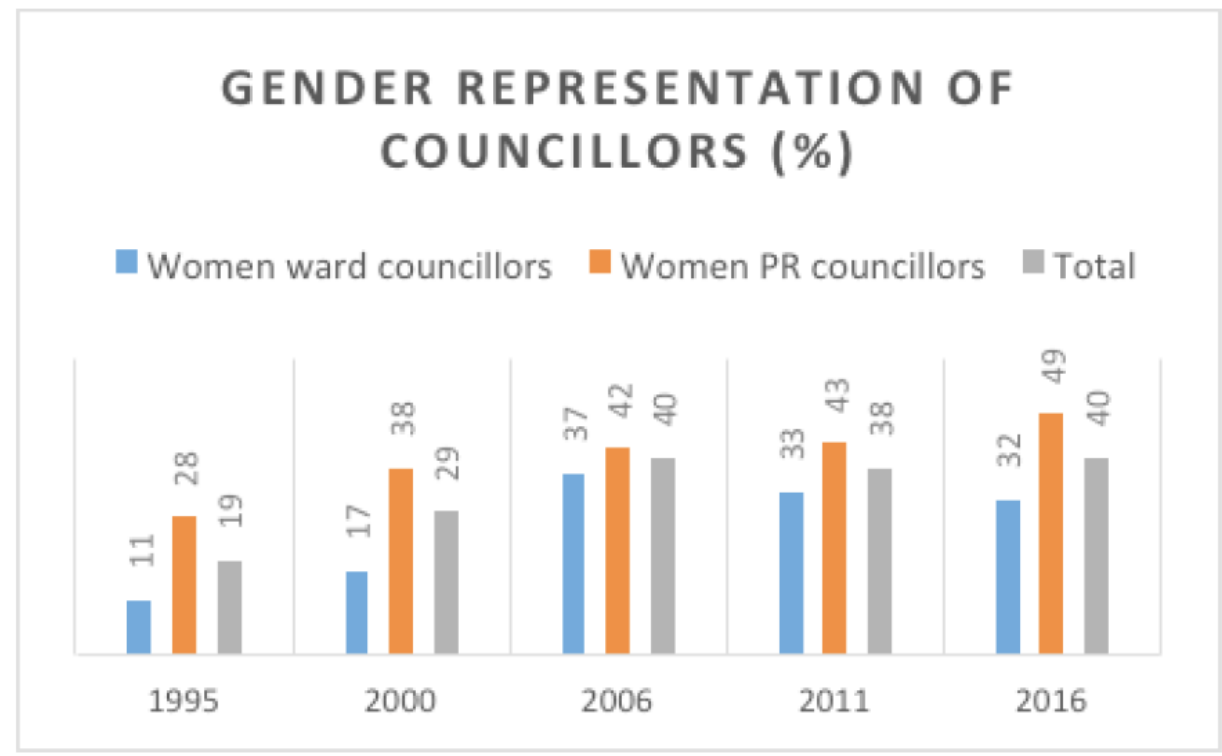

Figure 1: Gender Representation of Councillors.

Source: SALGA Women's Commission 2017.

\subsection{Salga Women's Commission}

The South Africa Local Government Association (SALGA) was established after 1996 in terms of s163 of the Constitution. Its mandate is to transform local government to enable it to fulfil its developmental mandate by protesting and representing the interests. At the Women in Local Government Summit in 2010, SALGA Women's Commission was launched to pursue the $50 / 50$ campaign that guarantees women $50 \%$ of elected positions in local government in terms of Article 4 of the SALGA constitution. The 2016 municipal elections were the fourth elections after the reformation of local government in 1995.

Figure 1 reflects the election of both women ward and PR councillors between 1995 and 2016, which was the last local elections in South Africa. One can notice an increase in the number of women ward councillors elected from 11 in 1995; to 17 (2000); and 37 (2006). However, there was a decline in the number of women ward councillors down to 33 in 2011 and again 32 in 2016. There must be some factors causing the numbers to decline, hence, the reason to conduct this study. Furthermore, women are increasingly assuming leadership roles in local government; the target of $50 \%$ female local councillors has still not been met, despite good progress over the last two decades (SALGA Women's Commission 2017). The commissioners, who then commit themselves to overcome challenges faced by women councillors in municipalities, noted the reversal towards the 50/50 gains in the last elections.

\section{RESEARCH METHODOLOGY}

The study adopted an exploratory research design and is qualitative in nature. It focuses on six local municipalities of the two provinces in the Republic of South Africa, namely, KwaZulu-Natal (KZN) and the Eastern Cape (EC). The provincial estimates showed that $\mathrm{KZN}$ has the second largest population, with 10.8 million $(21.4 \%)$ people, after Gauteng with, 11.3 million (22. 4\%) people (Dlova; Mankahla; Madala; Grobler and Tsoka-Gwegweni 2014). The EC is in third place with 14 per cent (South African Government Information, 2017). In KZN, four local municipalities under UMgungundlovu District were involved namely, uMsunduzi, uMngeni, uMshwati and uMkhambathini Local Municipalities. EThekwini Metropolitan Municipality, the only metro in KZN, which has 103 wards, was also involved in the study. The EC Province is situated in the eastern part of South Africa and the study focused on Mzimvubu Local Municipality under Alfred Nzo District Municipality. In KwaZulu-Natal 78 out of 341 councillors were interviewed, in the Eastern Cape, 26 out of 54 councillors took part from the only municipality that was targeted. There were twenty-three (23) women ward councillors; thirty-seven (37) male ward councillors, thirty (30) women PR councillors and fourteen (14) male PR councillors that participated in the study.

In-depth semi-structured interviews were adopted to allow the respondents to be flexible when responding to questions. Face-to-face interviews were conducted 
and the telephone was used due to the geographic dispersion of the respondents especially from the EC. Data was collected using secondary information such as annual municipal reports, national policies and local government prescripts and other publications. Content analysis was used and themes were induced from the interview data. Data was presented in the form of tables and percentages. The gatekeeper's letter was obtained from all targeted municipalities and the issue of confidentiality was communicated to all respondents.

\section{FINDINGS AND DISCUSSION}

The results were analysed and presented using tables which list the themes and the frequency of the responses. The respondents were asked to identify factors contributing to a high or low number of women councillors at the local government level. The majority of respondents were consistent in their responses that the number of women councillors was low. However, there were those who felt that the number is high because of the quota system as highlighted in Table 1 below.

The majority of respondents $16 \%(n=17)$ indicated lack of confidence in women is one of the factors contributing to their low numbers as ward councillors. Respondent 88 stated that "the problem with women, they are not confident in themselves...who would be confident in you if you are not confident in yourself". This finding is in line with Khan and Ara (2006) who stated that patriarchal norms and state laws keep women councillors in a lower status than men which result in their lower self-confidence. According to Batliwala and Veneklasen (2012), one may feel excluded within oneself, and that is expressed usually in terms of low self-confidence, self-esteem, control over their bodies. That is exactly how women feel when they are in an unfamiliar political space. Markhams (2013) and Nsana and Kabubi (2017) argued that political party leaders are complaining that there is a shortage of willing and trained women candidates with the requisite confidence and experience to stand for election. Political parties are key stakeholders in women's political empowerment and election as ward councillors. The challenge is that women are not groomed by their political parties and therefore lack confidence and experience.

Fifteen percent $(n=16)$ of the respondents mentioned lack of formal education as contributing to the low numbers of women ward councillors. Respondent 4 remarked that "When women are nominated, they decline to take positions because they are not politically matured, feel inferior and lack education in general". One of the aims of UN Women is to address unequal access to education and training. According to the Demand-Side and Supply-Side Framework by Norris and Lovenduski (1995), when people are educated they also understand and become motivated in joining politics. There are different stakeholders which could ensure that women ward councillors or women, in general, have access to

Table 1: Factors Contributing to High/Low Number of Women Councillors

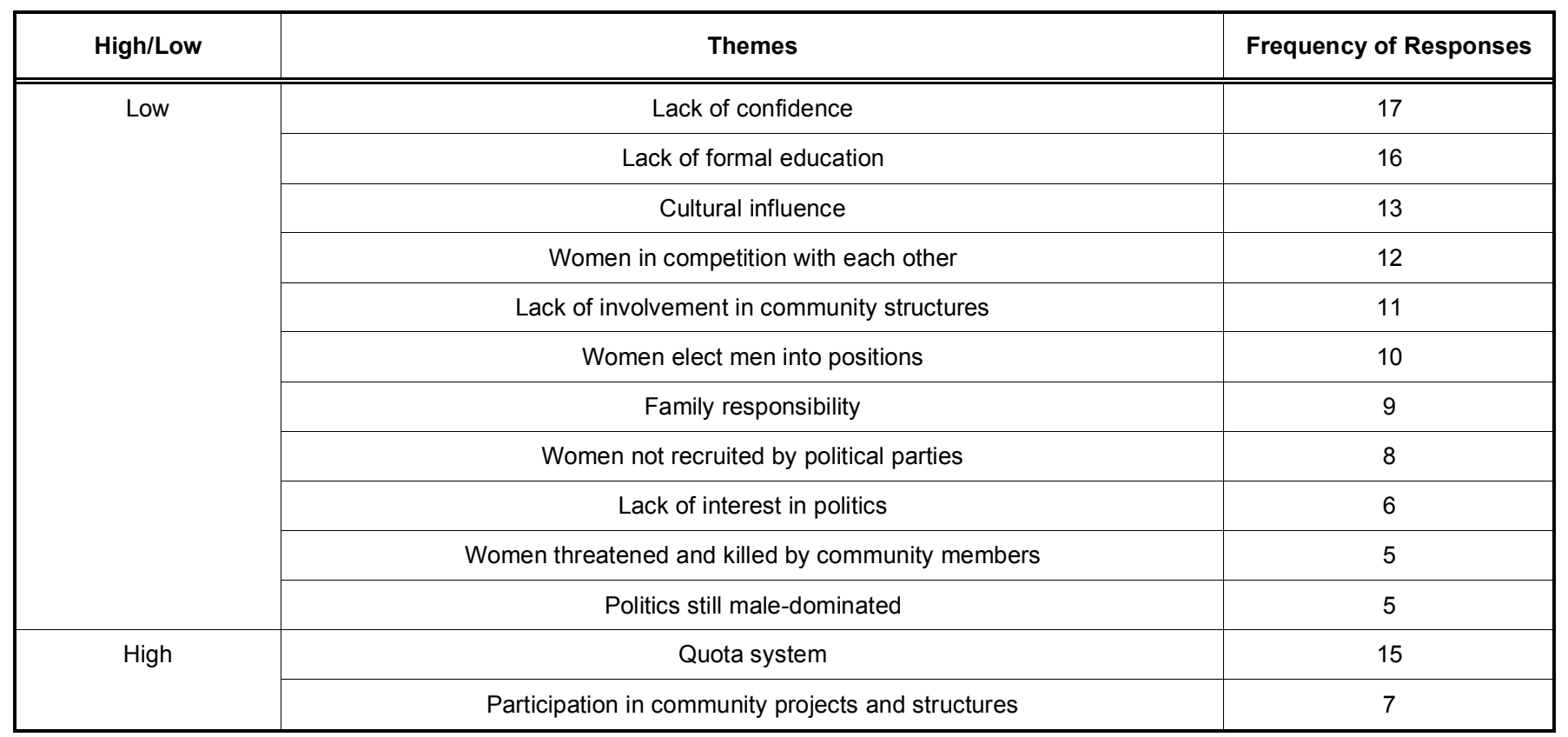


education as discussed above. The State can play a role by providing opportunities for education which is part of social inclusion in terms of UN Chapter 1 (2016). Parents can empower their daughters by investing in their education which is in line with the study conducted in Tanzania by Meena et al. (2017). Civil society organisations such as Equal Education can ensure that women have access to education from an early age. The findings are also in line with the study by Nsana and Kabubi (2017) which found that lack of access to well-developed education and training systems for women's political leadership and for orienting young women towards political life is a cause for their lack of participation. Furthermore, Mungai (2014) pointed out that all women councillors interviewed reported receiving training on campaign skills before elections, very few had received training after they were elected. It must be noted that education is free for some in South Africa as many people including women are restricted by financial constraints due to lack of facilities in rural public schools. Kunovich et al. (2007) and Kassa (2015) warned that education without cultural changes, women could still face barriers to participate in politics.

Thirteen respondents $(12 \%)$ reported that cultural influence is affecting the number of women ward councillors. This is in line with Bauer and Britton (2006) who stated that the existence of the patriarchal culture contributed to the low number of women in politics, which is also due to the socialization process, according to Idanga (2015). Culture affects women as community members and even within their political parties when a woman has to take a decision to enter politics, to party selection of candidates and to decisions made by voters on the election day (Kassa 2015). Nhundu et al. (2017) argued that when communities do not recognize women as politicians and decision-makers that can be a barrier for them to enter local government.

Eleven percent $(n=12)$ of the respondents reported that women are competing with each other. Respondent 104 mentioned that "women undermine each other...there are proportional representative councillors but as women, we don't support each other". Women compete for ward seats just like men as the number of seats is limited. The findings are in line with Parke et al. (2017) who warned that women's organizations and female politicians are not necessarily working towards a common goal but compete with each other. The International Women's Development Agency (2018) reiterate that even legislated quotas force women to compete against other women rather than supporting each other. Women ward councillors have more power and recognition than proportional representative councillors who are not directly elected by communities.

Lack of involvement in community structures is another factor mentioned by eleven respondents. Respondent 26 pointed out that "women must be well known and be involved in community structures...there are people who are not happy to see women in the leadership positions". Women in civil society groups have been at the forefront of the political struggles in South Africa, and this facilitated their election into positions of power including ward councillors at the local level. According to the Constitution (Republic of South Africa), the local government must encourage the involvement of communities and community organizations in matters of local government (CLGF 2017) and strengthens the role of councillors for the benefit of all community groups including women. The Municipal Systems Act (2000) requires councillors and officials to play a key role in fostering community participation. However, many councillors have become estranged from communities and their critical concerns. The reality is that women have challenges when they have to attend community meetings. In order for a woman ward councillor to perform her duties, a husband must accompany the wife to attend an evening meeting with communities. Nonetheless, community structures became less active and even in numbers post-1994 in South Africa, which has affected the number of women's participation in community structures.

Ten respondents $(10 \%)$ indicated that it is women who elect men into positions. Respondent 34 said, "the constitution is assisting...the sector is still maledominated but it is women who vote for men". Women constitute the majority of the population and are the most affected when the government does not deliver. According to StatsSA (2019), there are more women than men in South Africa and the female population is on average poorer than the male population. It is argued that women participate in greater numbers in local-level politics with the purpose to fight against under-representation in decision-making positions (Phillips 1996; Hassim 2005). Unfortunately, women are not taking advantage of their numbers but choose to elect men instead. Nahar and Humaidan (2013) raised an important point regarding this finding by arguing that women themselves do not elect women because the electoral decisions are still not 
independent, instead of being subject to the masculine authority and to the customs and traditions that promote the status of men and reduce or marginalize the public presence of females.

Women are affected by family responsibilities according to $9 \%$ of the respondents. Respondent 30 stated, "a woman would look at her children and step back because she is very protective of her children". According to gender socialization, women are privately excluded by their families and through their ethnic groups and marriages. The status of women is low as women are seen as inferior, weak and cannot be trusted in making informed decisions. The findings are in line with Silbermann (2019) who argued that only women with supportive families run for office, whereas men are more likely to run in spite of discouragement from their families. Women of childbearing age become occupied with raising children and other responsibilities. They normally join politics later in life when their children are older.

Eight percent of the respondents $(n=8)$ indicated that political parties are not recruiting women. Respondent 57 stated, "I don't think political parties do look for female candidates". Respondent 4 added that "even the party's Women's League is slow in recruiting women from rural areas". The findings are in line with UNDP (2015) which argued that political parties have not generally provided special assistance to attract women to the political arena. Furthermore, women participants in a study by Tunde (2014) revealed that there was no support from their political parties and government which made their entry into politics a challenge. This shows that political parties do not go out of their way in terms of recruiting and grooming women to be ready to contest the elections as ward councillors at the local level.

Respondents $(6 \%)$ reported that lack of interest in politics affects the numbers. Respondent 12 raised several factors with his comment mentioning that women are not supporting one another, family responsibility issues and that women, in general, are not interested in politics. The White Paper on Local Government (1998) ensure that the needs and interests of women are incorporated into municipal planning processes. When women's issues are a priority at the municipal level, political parties should ensure that they increase their numbers in order to engage them properly. The findings are in contravention with the supply-side perspective of the framework which suggests that political parties should focus on promoting conditions and opportunities that lead women to aspire for political office (International IDEA 2016). This view was also supported by Boeteng and Kosi (2015) who argued that the supply of woman available for political office is determined partly by gender socialization, which influences women's interest, knowledge, and ambition regarding politics.

Furthermore, five respondents (5\%) mentioned that community members threaten and kill women. Respondent 73 stated that "there are areas where women are threatened and killed especially in KwaZulu-Natal...most women can't face those challenges". The findings are in line with Mlambo and Kapingura (2019) who stated that politics is tarnished by violence, persecution, intimidation and torture. According to Bruce (2013), thousands of politicians have been killed in South Africa, including women, post-1994. In most cases, women prioritise their children and then decide not to join politics for fear of endangering their lives.

Five percent $(n=5)$ of the respondents remarked that politics is still male-dominated as another factor. Respondent 40 pointed out that "wards do not choose females...they don't trust them...the whole township and politics are dominated by men ". It is a fact that politics is male-dominated although there are national policies now challenging the status quo. Gender socialization trends are changing as more women have access to education in South Africa. However, Nhundu et al. (2017) argued that male-dominated political parties are not willing to involve women in their local branches and in local politics. This is negatively affecting the number of women ward councillors at the local level.

A number of respondents indicated that the number of women ward councillors in general are high for two different reasons. Firstly, $14 \% \quad(n=15)$ of the respondents indicated that the quota system contributed to the high number of councillors in the municipalities. Respondent 64 stated, "the 50/50 quota system allows both men and women to be equal especially in the council". The findings are in line with Meintjes and Simons (2002) and Tolmay and Morna (2010) who stated that the adoption of the quota policy by political parties can improve the representation of women local government. However, the number of women ward councillors has fluctuated in South Africa and most women in the councils are proportional representative councillors. With the adoption of a gender quota system by political parties, and having 
women on the party list can increase the number of women ward councillors in South Africa.

Secondly, seven respondents $(7 \%)$ mentioned that participation in community projects and structures contributed to the high number of women councillors. Respondent 23 stated, "there are women involved in community development projects and are leaders of support groups, for example, Siyayinqoba; Ubuntu Trust; and others participate in crime prevention...end up being elected as councillors". According to Nhundu (2008), women are good community mobilisers for a broad range of initiatives, including community-based activities and projects aimed to support political parties. Women who are active at branch or ward committee level can participate in projects initiated by their political parties and gain exposure. Community members may elect them into leadership positions as a result. However, DPME (2017) warns that the link between councillors and citizens via the ward committee system needs to be improved.

\section{CONCLUSION}

The study investigated factors affecting the number of women ward councillors in South Africa. Evidence indicates that the number of women ward councillors is low because of many factors. Lack of confidence and lack of education including political education are factors that negatively affect not only women in general but women who are already members of the municipal councils as a ward or proportional representative councillors. The study found that cultural influence; women in competition with each other; lack of involvement in community structures; women electing men into positions; family responsibilities; women not recruited by political parties; lack of interest in politics; women threatened and killed by community members; and that politics is still male-dominated as the main factors affecting the low number of women ward councillors in South Africa. However, the gender quota system and women's participation in community projects and structures were the reasons for the high number of women ward councillors in South Africa. South Africa will hold its local government elections in 2021 and it is crucial for all relevant stakeholders such as families, communities, civil society, government and political parties to work together in ensuring that more women are recruited and groomed to join politics and contest the elections as they are the majority and are mostly affected when municipalities do not deliver. The equal participation of women and men especially at the local government level will ensure the legitimacy and health of democracy in South Africa.

\section{REFERENCES}

Ahikire, J. 2004. "Towards Women's Effective Participation in Electoral Processes: A Review of the Ugandan Experience." Feminist Africa 3:8-26.

Baker, K. 2015. Women Candidates in the 2015 Bougaininville Election, SSGM Discussion Paper 2015/14, State, Society and Governance in Melanesia, ANU Online: http://ssgm.bellschool.anu.edu.au/sites/default/files/publicatio ns/attachments Accessed: 07/07/2019

Batliwala, S and Veneklasen, L. 2012. Social Exclusion and Access to Resources-Expanding Our Analytical Framework. JASSAWID Forum.

Bauer, G., and Britton, H.E. 2006. Women in African Parliaments Boulder CO: Lynne Rienner.

Bleidorn, W., Denissen, J.J.A., Gebauer, J.E., Arslan, R.C., Rentfrow, P.J., and Potter, J. 2016. "Age and Gender Differences in Self-Esteem-A Cross-Cultural Window." Journal of Personality and Social Psychology 111(3):396410. https://doi.org/10.1037/pspp0000078

Boeteng, J.S., and Kosi, I. 2015. "Women's Representation and Participation in District Assemblies in Ghana: Analysis of Supply-Side and Demand-Side Framework." International Journal of Scientific and Research Publications 1(10):1-6.

Bruce, D. 2013. "A Provincial Concern? Political Killings in South Africa." SA Crime Quarterly 45:1-48. https://doi.org/10.4314/sacq.v48i1.5

Cardo, M. 2014. "Social Inclusion and Policymaking in South Africa: A Conceptual Overview." The Journal of the Helen Suzman Foundation 73:7-15.

CLGF, 2017. The Local Government System in South Africa. Online: www.clgf.org.uk/south-africa Accessed: 07/07/2019

DPME, 2017. Governance and Administration: Twenty Year Review. Department of Planning, monitoring and Evaluation. Online: http://www.dpme.gov.za/news/Documents/20\%20Year\%20R eview.pdf Accessed: 09/08/2019

Dlova, N.C., Mankahla, A., Madala, N., Grobler, A., and TsokaGwegweni, J. 2014. The Spectrum of Skin Diseases in the Black Population, Durban, KwaZulu-Natal, South Africa. International Journal of Dermatology, Society of Dermatology Report 2014. https://doi.org/10.1111/ijd.12589

Fick, G. 2000. "The Importance of Equality to the Sphere of Local Government." Agenda 45:27-39. https://doi.org/10.2307/4066314

Goetz, P. 2003. "The Effects of Bilingualism on Theory of Mind Development." Bilingualism: Language and Cognition 6:1-15. https://doi.org/10.1017/S1366728903001007

Hassim, S. 2005. A Conspiracy of Women: The Women's Movement in South Africa's Transition to Democracy. Social Research 69(2):693-732

Idanga, G.E. 2015. "African Culture and Values." Phronimon 16(2). https://doi.org/10.25159/2413-3086/3820

International Women's Development Agency, 2018. Women's Political Leadership Strategy: Women's Action for Voice and Empowerment (WAVE) Program. IWDA, Melbourne.

International IDEA, 2016. A Framework for Developing Gender Policies for Political Parties. International Institute for Democracy and Electoral Assistance, Stockholm. 
Kasomo, D. 2012. "Factors Affecting Women Participation in Electoral Politics in Africa." International Journal of Psychology and Behavioural Sciences 2(3):57-63. https://doi.org/10.5923/j.ijpbs.20120203.01

Kassa, S. 2015. "Challenges and Opportunities of Women Political Participation in Ethiopia." Journal of Global Economics $3(4): 1-7$. https://doi.org/10.4172/2375-4389.1000162

Khan, R. M, and Ara. F. 2006. Women, Participation and Empowerment in Local Government: Bangladesh Union Parishad Perspectives. Asian Affairs 29:73-100

Krook, M.L. 2010. "Why Are Fewer Women Than Men Elected? Gender and the Dynamics of Candidate Selection." Political Studies 8:155-168. https://doi.org/10.1111/j.1478-9302.2009.00185.x

Kunovich, S., Paxton, P., and Hughes, M. 2007. "Gender in Politics." Annual Review Sociology 33:263-270. https://doi.org/10.1146/annurev.soc.33.040406.131651

Mandyoli, L. 2016. 2016 Local Government Elections: An Examination of Youth Participation. South African Catholic Bishop's Conference. Parliamentary Liaison Office. Briefing Paper 416.

Markham, S. 2013. Women as Agents of Change: Having Voice in Society and Influencing Policy. Online: http://documents.worldbank.org/curated/en/77345146815028 7912/pdf/927590NWPOWome00Box385358B00PUBLIC0.pdf Accessed: 24/10/2019

Mlambo, C., and Kapingura, F. 2019. "Factors Influencing Women Political Participation: The Case of SADC Region." Cogent Social Science 5:1-13. https://doi.org/10.1080/23311886.2019.1681048

Meintjes, S., and Simons, M. 2002. Why Electoral Systems Matter to Women. In G. Fick; S. Meintjes; and M. Simons. Eds, One Woman, One Vote. Johannesburg: Electoral Institute of Southern Africa.

Meena, R., Rusimbi, M., and Israel, C. 2017. Women and Political Leadership: Facilitating Factors in Tanzania. Research Report 17/1, UONGOZI Institute. Tanzania: 1-59.

Mungai, P.W. 2014. "Factors Influencing Women Participation in Political Process: The Case of the Orange Democratic Movement Party, Kenya." Masters Dissertation, Department of Extra-Mural Studies, University of Nairobi, Nairobi.

Nahar, G.S. 2003. "Democracy and the Status of Women Political Participation in the Arab World." International Journal of the Humanities 1:1875-1889.

Nahar, G.S., and Humaidan, R.L. 2013. "The Factors Affecting the Women's Political Participation in Jordanian Parliamentary Elections (2003-2013)." International Journal of Humanities and Social Science 3(1):84-94.

Nasreen, N., Sanauddin, N., and Gul, S. 2016. "Patriarchal Politics: Factors Limiting Women's Political Participation in Local Government in Pakistan." PUTAY-Humanities and Social Sciences 23(2):73-85.

Norris, P., and Lovenduski, J. 1995. Political Recruitment: Gender, Race and Class in the British Parliament. Cambridge University Press. England. https://doi.org/10.1017/CBO9780511598609

Nhundu, R.K., Lokar, S., Goni, O., and Senol, N. 2017. Consolidated Response on Women's Political Participation in Local Governments. Online: http://www.iknowpolitics.org/en/node Accessed: 09/08/2019

Nhundu, R. 2008. Expert Opinion on women in Local Governments: Incorporate Gender Perspectives in Politics and Policies. Online: http://www.iknowpolitics.org/en/node/8097Paxton Accessed: 09/08/2019

Nsana, S., and Kabubi, M. 2017. Factors Affecting Women's Political Participation in Lusaka: A Case Study of Kabwata and Munali Constituencies. The International Journal of Multi-
Disciplinary Research. Online: https://www.researchgate.net/ publication/327690671 Accessed: 01/10/2019

O'Neil, T., and Domingo, P. 2016. Women and Power: Overcoming Barriers to Leadership and Influence. Online: https://www.odi.org/publications/10309.women-powerovercoming-barriers-leadership-and-influence Accessed: $24 / 05 / 2019$

Parke, A., Stevens, S., Walls, M., Gaid, S., Ali, S., Butterfield, S., Elder, C., and Le Deat, D. 2017. Somali Women's Political Participation and Leadership-Evidence and Opportunities. UK Department for International Development. London: Social Development Direct and Forcier Consulting.

Phillips, A. 1996. Feminism and the Attractions of the Local. In D. King and G. Stroker. Returning Local Democracy. England: MacMillan https://doi.org/10.1007/978-1-349-24756-1 6

Republic of South Africa. 1996. Constitution of the Republic of South Africa of 1996. Pretoria: Government Printer.

Republic of South Africa. 1998. The White Paper on Local Government of 1998. Pretoria: Government Printer.

Republic of South Africa.1998. The Local Government Municipal Structures Act No. 117 of 1998. Pretoria: Government Printer.

Republic of South Africa. 2000. The Local Government Municipal Systems Act No. 32 of 2000. Pretoria: Government Printer.

Robinson, J. 1995. "The Act of Omission: Gender and Local Government in the Transition." Agenda 26:7-18. https://doi.org/10.2307/4065913

Rosenbluth, F., Kalla, J., and Teele, D. 2015. The Female Political Career. Women in Parliament Global Forum. The World Bank.

SALGA Women's Commission, 2017. The Journey (2010-2016): Working Together to Promote Gender Equality, Sustainable Development and Good Governance. South African Local Government Association: Pretoria.

Segalo, P. 2015. "Gender, Social Cohesion and Everyday Struggles in South Africa." Psychology in Society 49:70-82. https://doi.org/10.17159/2309-8708/2015/n49a6

Selokelo, T. 2014. "The Representation of Female Councillors in South African Municipal Elections." Journal of Peacebuilding and Development 9(3):95-101. https://doi.org/10.1080/15423166.2014.983368

Silbermann, R. 2019. "Gender Roles, Work-Life Balance, and Running for Office." Quarterly Journal of Political Science. Online: https://sites.google.com/site/rachelsilbermann/ research Accessed: 14/07/2019

Spark, C., and Corbett, J. 2016. “Emerging Women Leaders' View on Political Participation in Melanesia." International Journal of Politics 20(2). https://doi.org/10.1080/14616742.2016.1189680

StatsSA. 2019. Gender Statistics in South Africa, 2019. Statistics South Africa. Online: http://www.statssa.gov.za/publications/ Report-03-19-05.pdf. Accessed: 27/10/2019

Tolmay, S. and Morna, C.L. 2010. Consolidating Democratic Governance in the SADC Region. In Gender Links. Eds. This Seat is Taken: Elections and the Under-representation of Women in Seven Southern African Countries. Johannesburg: EISA.

Tunde, T.E. 2014. "Factors Influencing Women Participation in Political Leadership: The Case of Kimilili Constituency of Bungoma County, Kenya." Global Advanced Research Journal of Geography and Regional Planning 3(1):1-31.

UNDP, 2015. Where are the Women? A Study of Women, Politics, Parliament, Equality in the CARICOM. United Nations Development Programme.

UN Estimates, 2019. Population of South Africa (2019 and Historical). Online: https://www.worldometers.info/worldpopulation/south-africa-population/ Accessed: 14/07/2019. 
UN Chapter 1, 2016. Report on the world social Situation-Identifying Social Exclusion and Inclusion. Online: https://www.un.org/ development/desa/dspd/world-social-report/rwss2016.html Accessed: 29/11/2019.
Zapata, A.D.G. 2018. "Women's Leadership and Political Participation: Fair Access to Political Spheres in the Province of Bulacan, Philippines." African Educational Research Journal 6(4):334-341. https://doi.org/10.30918/AERJ.64.18.102

DOI: https://doi.org/10.6000/1929-7092.2020.09.35

(c) 2020 Brian Kwazi Majola; Licensee Lifescience Global.

This is an open access article licensed under the terms of the Creative Commons Attribution Non-Commercial License (http://creativecommons.org/licenses/by-nc/3.0/) which permits unrestricted, non-commercial use, distribution and reproduction in any medium, provided the work is properly cited. 